\title{
2113 筒状体の軸围撃圧潰における変形制御
}

\section{Control of Crush Deformation of Tubular Structure in Axial Impact}

\author{
○山下 実(岐阜大工) \\ 服部 敏雄(岐阜大工) \\ Minoru YAMASHITA and Toshio HATTORI, Gifu university, 1-1 Yanagido Gifu-shi, Gifu
}

Keywords: Crush deformation, Plasticity, Impact, Tubular structure, Control

\section{1.はじめに}

車体等に対する安全性能の向上と軽量化の両立の要求に 対して, 著者の一人はハット型強度部材や各種筒状体の軸衝 撃圧潰変形挙動に関する一連の研究を行い, 各種断面形状が 変形に及ぼす影響を解明してきた ${ }^{1) \div 4)}$. 通常, この種の部材 には，所望位置に座屈変形を生じさせる必要があり，部材に 形状的初期不整等を設けることによって座屈を制御するこ とも行われている.

本報では，まず，初期形状不整を設けたハット型断面の筒 状体を用い, 座屈変形形状の制御を試みた。衝撃実験に加え て数値計算(DYNA3D ${ }^{5)}$ )でも検証した。 また, 以前に行った 形状不整を設けない実験において，座屈変形パターンが不規 則になる時, 圧潰強度が大きい場合があった。この現象につ いては数値計算で再現を試みた。

さらに，著者らは，筒状体の衝撃座屈変形において変形を 制御する方法として, 衝撃時に筒状体に生じる加速(减速)度 を利用して, 所望する箇所を座屈変形の起点とすることを考 えた。この制御法については，数值計算を援用して，その有 効性を確認した。

\section{2. ハット型強度部材における初期形状不軎による座屈夜形 の制御}

板厚 $1 \mathrm{~mm}$ の $590 \mathrm{MPa}$ 級高張力鋼板で，強度部材を製作し た. 断面形状と初期形状不整を Fig.1 に示す．軸方向の長さ は $200 \mathrm{~mm}$ ，フランジ部のスポット溶接ピッチは $20 \mathrm{~mm}$ であ る. 部材軸方向の形状不整として, ハット部品の角部に深さ $2 \mathrm{~mm}$ の $90^{\circ} \mathrm{V}$ 字状のくぼみを, Case-1: 下から $104 \mathrm{~mm}$ のみ, Case 2: 44, 84, 124, $164 \mathrm{~mm}$ および上端の 5 䇢所に付けた. 準 静的および落鍾衝撃試験機援用の衝撃実験(衝撃速度：10 $\mathrm{m} / \mathrm{s})$, 数值シミュレーションを行った. 溶接箇所は曲げ変形 に対する剛性が高いため, くぼみ位置は溶接中心から $4 \mathrm{~mm}$ 離した。

Case-2 について，実験および計算で得た圧潰変形過程を Fig.2 に示す. 共に形状不整を付けた箇所から座屈変形は開 始したが，くぼみの形状はすべて同一であるため, 衝撃速度 $10 \mathrm{~m} / \mathrm{s}$ 程度では衝撃端のくぼみが開始位置にはならなかっ た。また，実験，計算とも，形状不整の影響である振幅の小 さいうねりが圧潰の初期段階から生じた. 変形進行中も保持 されており, 繰返し座屈変形の態様と相関性を持つ。もちろ ん，開始位置を定めるには，〈ぼみ寸法を工夫すればよい。

各種条件下のクラッシュ強度(圧潰力/材料部分の断面積) を Fig.3 に示した。実験では初期形状不整を付けた場合, ク ラッシュ強度はやや増加した，一方，計算では若干低下した が, 有意差とは見なし難く,この程度の初期形状不整はクラ ッシュ強度に影響をほとんど及ぼさないと言える。

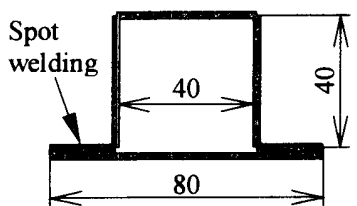

(a) Cross-sectional shape

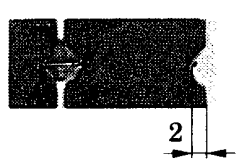

(b) V-shaped dimple
Fig. 1 Cross-sectional shape and $90^{\circ}$ V-shaped dimple. (Sheet thickness: $1.0 \mathrm{~mm}$, Longitudinal length: $200 \mathrm{~mm}$ )

\section{3. ハット型强度部村におけるクラッシュ強度の制御}

衝撃圧潰変形において，初期形状の対称面に関して，左右 の対称性をほぼ保った例と, 変形中に非対称形状の変形を示 した例を Fig.4(板厚 $1 \mathrm{~mm}$ の $440 \mathrm{MPa}$ 級高張力鋼板)に示す. それぞれのクラッシュ強度は, 81MPaおよび 100MPaであり， 非対称となった場合の方が $20 \%$ 以上高かった. 非対称形状に なった要因は, 溶接位置などの複合的要因によるものであろ うが, 変形の不規則性が不測的余剩変形を誘発し, 結果的に クラッシュ強度が上昇したものと考えられる。

この現象は, 圧潰中に任意箇所で形状の対称性が崩れるも のである。これを数值計算で再現するため, ハット部の三面 上の節点すべてに面外方向に不規則な寸法的擾乱を与えた. これも形状不整の一種であるが，不整が特定箇所に偏らない ところが異なる。部高さの最大值 $\delta$ を種々に規定し，各節

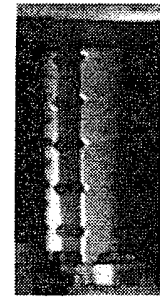

Initial

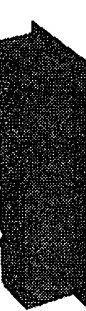

Initial

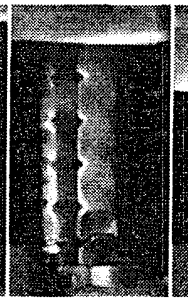

$T=2 \mathrm{~ms}$

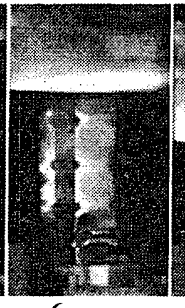

$6 \mathrm{~ms}$

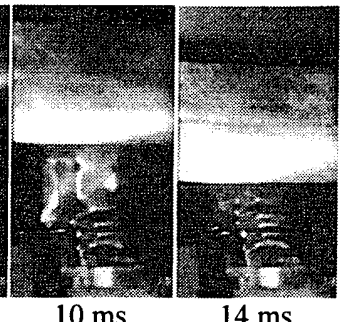

$10 \mathrm{~ms}$

$14 \mathrm{~ms}$ (a) Impact experiment

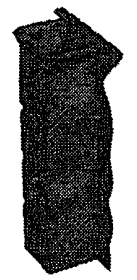

$T=1 \mathrm{~ms}$

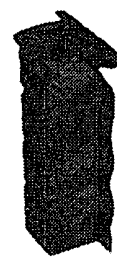

$2 \mathrm{~ms}$

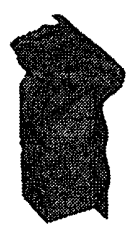

$4 \mathrm{~ms}$

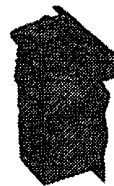

$6 \mathrm{~ms}$

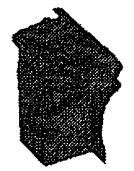

$8 \mathrm{~ms}$ (b) Computation

Fig.2 Progressive deformation patterns where V-shaped dimples are introduced at corners of hat part.

Material: 590MPa class high strength steel

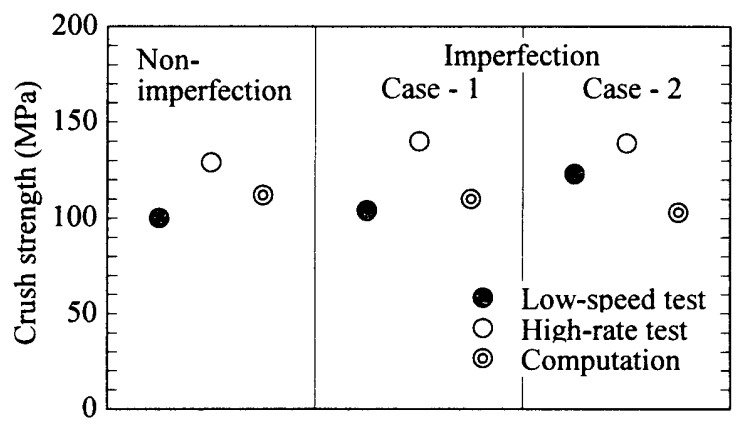

Fig.3 Crush strengths where V-shaped dimples are introduced at corners of hat part.

[№.04-53] 日本機械学会第 13 回交通・物流部門大会講演論文集 [2004-12.1～3. 川崎] 


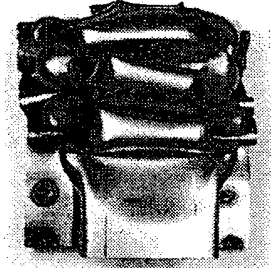

(a) Regular pattern

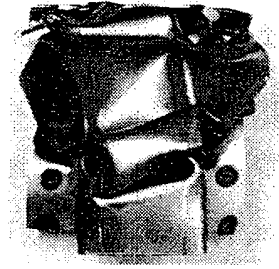

(b) Irregular pattern
Fig.4 Regular and irregular collapse patterns. Material: 440MPa class high strength steel

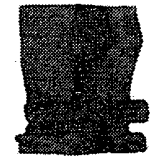

$\delta(\mathrm{mm}): 0.05$

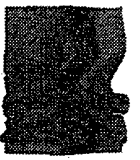

0.25

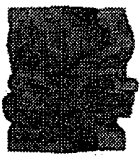

1.00

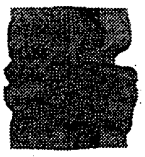

1.50

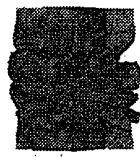

2.00
Fig.5 Crush patterns for various wavy faces in computation.

点の凸寸法は乱数を使用して与えた.

各 $\delta に$ 対する圧潰形状とクラッシュ強度をそれぞれ Fig.5 に示す. $\delta=2.00 \mathrm{~mm}$ においては，変形形状が明らかな左右 非対称を示しクラッシュ強度が比較的高く, 実験で見られた 現象をシミュレートできた。ここで採った方法は，不規則な 変形形状を積極的に誘起する一つの実際的な方法となり得 るものと考える.

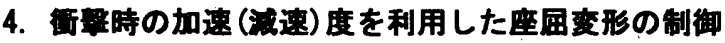

車両においては主として想定する衝突速度は $10 \mathrm{~m} / \mathrm{s}$ 程度 である。この速度域において局所的に部材の特性を変えずに (くぼみ等によらずに), 繰り返し座屈変形を所望位置で生じ させることができれば，より好ましい制御法と言えよう。

そこで, Fig.6 に示すように正方形断面の筒状体を対象と して，側面に板状の小さい錘を設け，これを繰り返し座屈変 形の基点とする制御法について, 数值計算で検証を試みた. すなわち，筒状体に加速度が生じる時，その錘の慣性を利用 して側壁に曲げ変形を強いるのである。

質量 $100 \mathrm{~kg}$ のブロックと一体になった長さ $400 \mathrm{~mm}$ の筒状 体が，固定壁に衝突することを想定した。筒状体は一辺 50 $\mathrm{mm}$ の正方形断面で, ヤング率 $72 \mathrm{GPa}$ ，ポアソン比 0.34 , 塑 性特性は $\sigma=314 \varepsilon^{0.084} \mathrm{MPa}$ で与えた. 座屈変形の基点制御用 の錘の寸法は， $20 \times 20 \times 5$ (厚み) $\mathrm{mm}$ で質量は $20 \mathrm{~g}$ である. 筒状体の衝㔖端から $40 \mathrm{~mm}$ の位置に対面に 2 箇所付けた。

制御用の錘を付けない通常筒状体および制御用の錘を付 けた壁厚 1.0 および $2.0 \mathrm{~mm}$ の筒状体について, 変形進展の 様子を Fig.7 に示す. まず，制御用の錘を付けない通常筒状 体においては, 質量 $100 \mathrm{~kg}$ のブロックとの結合箇所で座屈変 形が始まり，そこから変形が進展した。一方, 制御用の錘を 付けた壁厚 $1.0 \mathrm{~mm}$ の筒状体では, 一旦, 質量 $100 \mathrm{~kg}$ のブロ ックとの結合箇所で座屈変形が始まるものの, 制御用の錘が 新たな座屈変形を強制的に生じさせ, ブロックとの結合箇所 での座屈変形を停止させていることがわかる，そして，繰り 返し座屈変形は制御用の鏵を付けた筒所から進行した.なお， 筒状体の板厚が $2 \mathrm{~mm}$ の場合, 側壁部の曲げ剛性が高く座屈 変形の制御ができない結果となった.

この方法は, 強度部材の剛性を通常使用時に犠牲にするこ となく，所望の筒所を保護できる方法であり，筒状体以外の 変形制御にも可能なものと考える.

\section{考文糔}

1) M. Gotoh et. al., NUMIFORM 2001, 2001, pp. 945-950.

2) 山下実ほ力, 機論 A, 68-666, 2002, pp.217-212.

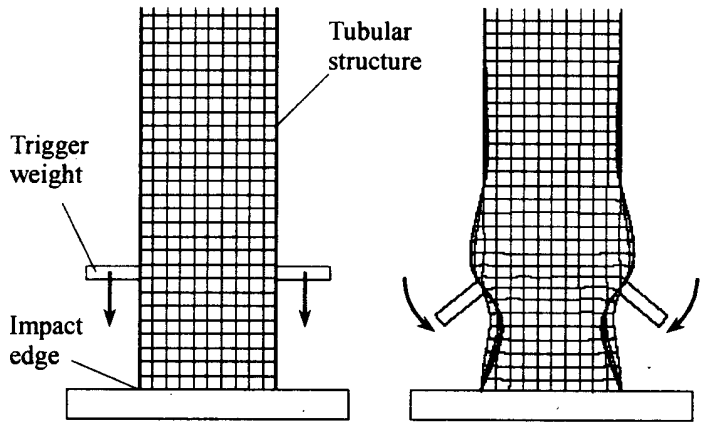

Fig.6 Schematic illustration of bending deformation of the structural wall induced by the trigger weight.

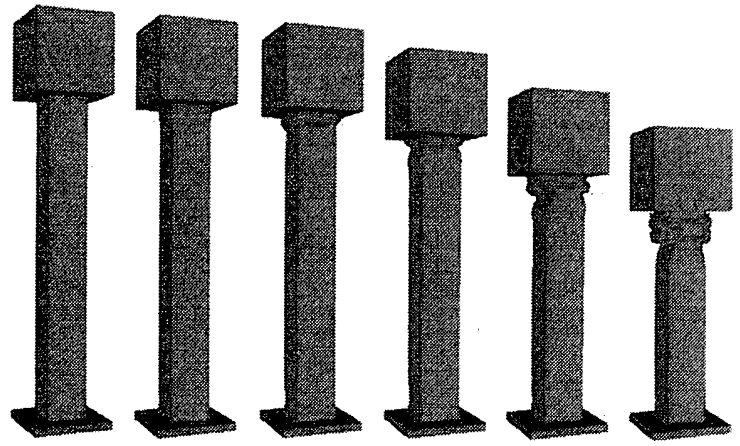

(a) No trigger weight, Wall thickness: $1.0 \mathrm{~mm}$

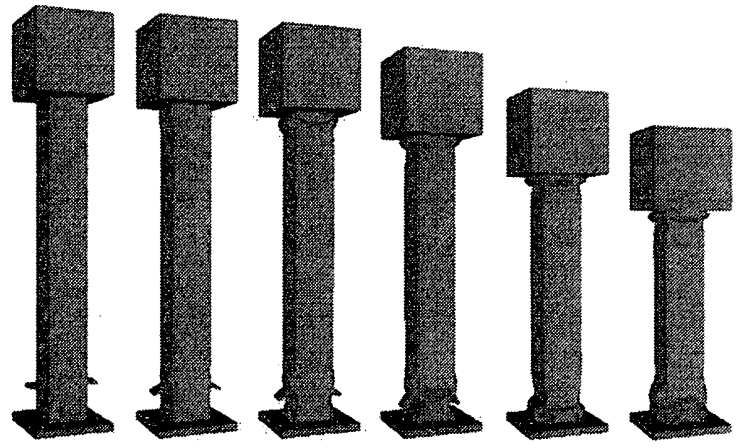

(b) Trigger weight attached, Wall thickness: $1.0 \mathrm{~mm}$

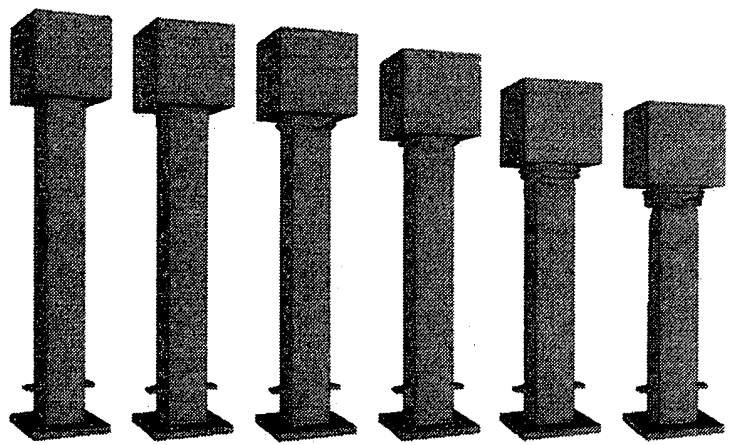

(c) Trigger weight attached, Wall thickness: $2.0 \mathrm{~mm}$

Fig.7 Progressive collapse patterns of moving square column and weight into rigid wall.

3）山下実ほか, 機論 A, 68-668, 2002, pp.668-673.

4) M. Yamashita et al., J. Mat. Proc. Tech., 140, 2003, pp.59-64.

5) Hallquist, J.O.: DYNA3D, User's manual Rev.5, 1989. 